Article

\title{
Recognitive Approach to the Energy Policies and Investments in Renewable Energy Resources via the Fuzzy Hybrid Models
}

\author{
Shubin Wang ${ }^{1,2,3}$, Weijie $\mathrm{Li}^{2}$, Hasan Dincer ${ }^{4}\left(\mathbb{D}\right.$ and Serhat Yuksel ${ }^{4, *(1)}$ \\ 1 School of Economics and Management, Xi'an University of Posts \& Telecommunications, Xi'an 710061, \\ China; wangshubin@stu.xjtu.edu.cn or wangshubin1228@163.com \\ 2 Shaannan Eco-Economy Research Center, Ankang University, Ankang 725000, China; liweijie@aku.edu.cn or \\ liweijie8866@aliyun.com \\ 3 Western Institute of Digital Economy, Xi'an 710121, China \\ 4 School of Business, Istanbul Medipol University, Istanbul 34815, Turkey; hdincer@medipol.edu.tr \\ * Correspondence: serhatyuksel@medipol.edu.tr
}

Received: 4 October 2019; Accepted: 19 November 2019; Published: 28 November 2019

\begin{abstract}
This study aimed to evaluate the energy policies and investments in renewable energy resources. In this context, developing energy policy and investing in energy were defined as two different factors for renewable energy. Additionally, eight different criteria were also selected based on these two different factors. In the first stage of the analysis, these criteria were evaluated by using a correlation coefficient based on interval type- 2 fuzzy sets. The findings show that five criteria have a relationship with policy factors, whereas seven criteria are related to the investment factor. After that, the fuzzy DEMATEL approach based on interval type-2 fuzzy sets were used to weight these criteria. It was identified that policy returns, policy facilities, and policy technology were the most important criteria. Additionally, a performance evaluation of renewable energy investment alternatives was made with a fuzzy TOPSIS approach based on interval type-2 fuzzy sets. It was concluded that wind and solar are the most significant renewable energy investment alternatives. Therefore, it is recommended that there should be government supports for wind and solar energy investments. Within this context, corporate tax discounts for these companies, customs duty decrease for the items used in the investments, and providing qualified personnel in this area can attract the attention of these investors.
\end{abstract}

Keywords: investment; policy; renewable energy; correlation coefficients; DEMATEL; TOPSIS; interval type-2 fuzzy sets

\section{Introduction}

Renewable energy refers to the type of energy in which resources are not limited and can be renewed continuously [1,2]. Because renewable energy has unlimited resources, it has attracted the attention of investors. However, in this circumstance, investors should focus on many different factors at the same time in order not to have a loss [3]. For example, geographical conditions, legislation, and climate factors are very important items in this investment decision process. Investors should also make an analysis of the profitability and market conditions. Additionally, technological improvement should be provided for the countries to become successful in this process.

Therefore, the problem of the study is to evaluate the energy policies and investments with multidimensional factors. Hence, an effective methodology should be taken into consideration that includes both financial and nonfinancial issues. A balanced scorecard is an approach in the literature that is used to make performance evaluations. This method has four different dimensions, which are 
finance, customer, internal factors, and learning and growth. It can be said that nonfinancial items are also considered in addition to the financial factors [4].

In this study, it is aimed to examine the energy policies and investments in renewable energy resources. In this context, firstly, two different factors are defined for renewable energy, which are developing energy policy and investing in energy. In addition to this situation, eight different criteria are also identified based on these two different dimensions by evaluating important studies in the literature. These criteria are evaluated based on a balanced scorecard approach with the help of a correlation coefficient. After that, a fuzzy DEMATEL approach is used to weight criteria. This methodology is mainly used to understand the significance levels of different items [5,6]. In the final process of the analysis, renewable energy investment alternatives are ranked by considering fuzzy TOPSIS. The main purpose of this approach is to identify the most significant possibilities to make a decision under the complex environment $[7,8]$.

The findings of the study indicate that policy returns, policy facilities, and policy technology are the most important criteria for a renewable energy investment decision. Additionally, it is also concluded that wind is the most significant renewable energy investment alternative. This study has some important novelties. First of all, the fuzzy DEMATEL, fuzzy TOPSIS, and correlation coefficient methods are firstly used together in this study with the aim of evaluating renewable energy investment policies. In addition to this condition, criteria are prepared for renewable energy investment alternatives by considering significant studies in the literature. Hence, it is thought that this study has an important contribution to the literature.

\section{Literature Review}

The subject of generating policies and investment decisions in renewable energy attracted the attention of lots of researchers in the literature. They focused on this subject by considering many different ways. According to some studies, geographical conditions are very important for selecting renewable sources. For example, Castillo et al. [9] aimed to analyze the regional potential for solar power generation in their study. For this purpose, 28 different European countries are taken into consideration. They concluded that geographical factors play a very key role in this issue. Similarly, Leautier [10], Frantál and Prousek [11], Kumar and Samuel [12], and Chatterjee and Kar [13] also analyzed the same subject for different regions, such as Africa and the Czech Republic. They underlined the importance of geographical factors for generating policies and making investments for renewable energy.

In addition to these studies, the profits and return period of energy investments was also identified as a significant criterion for renewable energy investment decisions. De Boeck et al. [14] tried to identify the factors affecting renewable energy investment decisions. They focused on the European market and reached the conclusion that profitability is an essential criterion for making investments in renewable energy alternatives. Kim et al. [15], Alizamir et al. [16], and Reboredo et al. [17] also concluded that profitable renewable energy investment alternatives mainly attracted the attention of the investors. On the other side, Bruno et al. [18] explained the importance of the profitability for this issue, but they also underlined the significance of risk management in this process at the same time.

Moreover, ease of investment from the start-up to commercialization is a very critical factor for policy generation and making investment decisions for renewable energy according to some studies. For instance, Komendantova and Stepanova [19] underlined the importance of this factor for making renewable energy investments in Russia. Also, Jena et al. [20], Lv and Spigarelli [21], and Junlakarn et al. [22] presented other studies that reached similar conclusions for different countries. Furthermore, for some researchers, the legislation of the countries is an important factor for generating policies and investment decisions regarding energy. As an example, Chang et al. [23] focused on the factors that affect renewable energy investment decisions. In this framework, East Asia countries are evaluated in this study. They identified that the restrictions of obligatory authority and legal regulations make investors reluctant to make investments in renewable energy. Parallel to this study, Özkale et al. [24], 
Young and Brans [25], Morea and Poggi [26], and Hua et al. [27] also defined that when countries have hard legal restrictions, it has a negative influence on the investments in renewable energy.

Also, some researchers in the literature underlined the importance of climate factors for generating policies and investments for renewable energy. Strantzali and Aravossis [28] tried to define the indicators of renewable energy investment decisions. They reviewed many different papers on this subject. As a result, it was identified that weather conditions have an important effect on renewable energy investment decisions. Similarly, Chappin et al. [29] concluded that investors become unwilling to make investments when there are fast changes in the climate of the countries. This situation was also determined by Kober et al. [30] and Guerrero-Liquet et al. [31].

According to some studies, the experience of the company is one of the most significant factors that affect renewable energy investment decisions. For example, Şener et al. [32] aimed to define the indicators of renewable energy investments. For this purpose, 60 different studies were evaluated out of 1431 academic studies. They concluded that the investor's experience plays a key role in this situation. Guerrero-Liquet et al. [31] also reached the same conclusion for the Dominic Republic. Additionally, de Arce et al. [33] and Radomes Jr and Arango [34] contributed other studies that determined that number of similar projects completed by the same team is essential for the success of renewable energy investments.

Another important factor that affects policy generation and investment decisions in renewable energy is the technological background of the company. For instance, Aflaki and Netessine [35] aimed to define the indicators of renewable energy investment decisions in their study. They determined that the infrastructure of research and development for innovative projects is the main factor for a company to become successful in renewable energy investment. Similar to this study, Salm et al. [36], Polzin et al. [37], and Lam and Law [38] also underlined the importance of technological factors in renewable energy investment. They mainly stated that companies should give significance to the research and development investment to be successful for this investment.

Furthermore, in some studies, it is claimed that geographical conditions are very important for renewable energy investment decisions. In this scope, Castillo et al. [9] focused on 28 European Union countries and underlined the importance of the regional potential for solar power generation. Similarly, Leautier [10] also identified the importance of the geographical conditions for African countries. On the other side, Frantál and Prousek [11] made an analysis for Czech farmers and reached a conclusion that geographic conditions play a very important role in biomass production. Also, Kumar and Samuel [12], and Chatterjee and Kar [13] produced other studies that defined the importance of this issue in selecting renewable sources.

On the other side, the significance of profitability and risk conditions was also identified by some researchers. For instance, De Boeck et al. [14] focused on the European market and identified that profitability should be the most important indicator in making a renewable energy investment decision. Alizamir et al. [16] also underlined the significance of the cost management strategies for this purpose. Moreover, Kim et al. [15] made an analysis for the hydropower projects in Indonesia and concluded that effective risk management is a must in selecting renewable energy investment alternatives. Reboredo et al. [17] and Bruno et al. [18] also claimed that volatility in the market should be taken into consideration for this purpose.

Additionally, some researchers in the literature also focused on the role of market conditions on renewable energy investment decisions. As an example, Ritzenhofen and Spinler [39] aimed to understand the ways to stimulate renewable energy investments. They concluded that the balance of supply and demand for competitive energy sources has an important influence on this issue. Moreover, Salm and Wüstenhagen [40] and Uyar and Beşikçi [41] also determined that companies should consider market conditions to be successful in renewable energy investments. 
While considering these studies in the literature, it is understood that there is broad literature on renewable energy investment. Most of these studies focused on the indicators of this decision. Additionally, various methodologies were considered in these studies, such as regression, survey, and causality analysis. Hence, it is concluded that there is a need for a new study that considers the issue of renewable energy with a different methodology, like fuzzy logic and the correlation coefficient. Hence, it is believed that considering this approach in this study for these purposes makes a significant contribution to the literature.

\section{Proposed Method}

A hybrid model is proposed for the balanced scorecard-based evaluation of renewable energy sources. In this framework, fuzzy logic is conserved, mainly due to the ability to deal with uncertainty. For this purpose, the analysis is classified in three stages, and they consist of several steps for ranking alternatives. In the first stage, the criteria are selected with the help of correlation coefficients. On the other side, the second stage is related to the calculation of the weights of criteria with DEMATEL. This method was firstly generated by the Geneva Research Centre of the Battelle Memorial Institute [42]. The main reason for selecting this approach is that it is possible to create an impact relation map of the criteria. In other words, a causality analysis can be performed by using this approach. Furthermore, in the third stage, renewable energy investment alternatives are ranked by using fuzzy TOPSIS methodology. This approach has many advantages, such as simplicity and considering a high number of alternatives. The proposed model is summarized in the following steps.

Stage 1: Select the criteria of each factor with correlation coefficients.

Step 1: Balanced scorecard-based linguistic evaluations are provided for each factor and criteria.

Step 2: The evaluations are converted into the trapezoidal fuzzy numbers.

Step 3: The matrices are defuzified by the ranking method for the trapezoidal interval type-2 fuzzy sets [43]. The method is given in Equations (1)-(4).

$$
\begin{gathered}
\operatorname{Def}\left(x_{i j}\right)=\operatorname{Rank}\left(\widetilde{x}_{i j}\right)_{m \times n}=M_{1}\left(\widetilde{A}_{i}^{U}\right)+M_{1}\left(\widetilde{A}_{i}^{L}\right)+M_{2}\left(\widetilde{A}_{i}^{U}\right)+M_{2}\left(\widetilde{A}_{i}^{L}\right)+M_{3}\left(\widetilde{A}_{i}^{U}\right)+ \\
M_{3}\left(\widetilde{A}_{i}^{L}\right)-\frac{1}{4}\left(S_{1}\left(\widetilde{A}_{i}^{U}\right)+S_{1}\left(\widetilde{A}_{i}^{L}\right)+S_{2}\left(\widetilde{A}_{i}^{U}\right)+S_{2}\left(\widetilde{A}_{i}^{L}\right)+S_{3}\left(\widetilde{A}_{i}^{U}\right)+S_{3}\left(\widetilde{A}_{i}^{L}\right)+S_{4}\left(\widetilde{A}_{i}^{U}\right)+\right. \\
\left.S_{4}\left(\widetilde{A}_{i}^{L}\right)\right)+H_{1}\left(\widetilde{A}_{i}^{U}\right)+H_{1}\left(\widetilde{A}_{i}^{L}\right)+H_{2}\left(\widetilde{A}_{i}^{U}\right)+H_{2}\left(\widetilde{A}_{i}^{L}\right), \\
M_{p}\left(\widetilde{A}_{i}^{j}\right)=\left(a_{i p}^{j}+a_{i(p+1)}^{j}\right) / 2,
\end{gathered}
$$

where $M_{p}\left(\widetilde{A}_{i}^{j}\right)$ is the average of the elements $a_{i p^{\prime}}^{j}$ and $a_{i(p+1)^{\prime}}^{j} 1 \leq p \leq 3$,

$$
S_{q}\left(\widetilde{A}_{i}^{j}\right)=\sqrt{\frac{1}{2} \sum_{k=q}^{q+1}\left(a_{i k}^{j}-\frac{1}{2} \sum_{k=q}^{q+1} a_{i k}^{j}\right)^{2}}
$$

where $S_{q}\left(\widetilde{A}_{i}^{j}\right)$ is the standard deviation of the elements $a_{i q}^{j}$ and $a_{i(q+1)^{\prime}}^{j} 1 \leq q \leq 3$,

$$
S_{4}\left(\widetilde{A}_{i}^{j}\right)=\sqrt{\frac{1}{4} \sum_{k=1}^{4}\left(a_{i k}^{j}-\frac{1}{4} \sum_{k=1}^{4} a_{i k}^{j}\right)^{2}}
$$

$H_{p}\left(\widetilde{A}_{i}^{j}\right)$ is the membership value of the element $a_{i(p+1)}^{j}$ in the trapezoidal membership function $\widetilde{A}_{i}^{j}$ $1 \leq p \leq 2, j \in\{U, L\} 1 \leq i \leq n$.

Step 4: The correlation of balanced scorecard-based factor A evaluation is

$$
C(A, A)=\sum_{i=1}^{n}\left(\frac{1}{l_{i}} \sum_{j=1}^{l_{i}} h_{A \sigma(j)}^{2}\left(x_{i}\right)\right)
$$


Step 5: The correlation between balanced scorecard-based factors A and criteria B is

$$
C(A, B)=\sum_{i=1}^{n}\left(\frac{1}{l_{i}} \sum_{j=1}^{l_{i}} h_{A \sigma(j)}\left(x_{i}\right) h_{B \sigma(j)}\left(x_{i}\right)\right) .
$$

Step 6: The correlation coefficient between factor A and criteria B is examined

$$
\rho(A, B)=\frac{C(A, B)}{\sqrt{C(A, A)} \sqrt{C(B, B)}}=\frac{\sum_{i=1}^{n}\left(\frac{1}{l_{i}} \sum_{j=1}^{l_{i}} h_{A \sigma(j)}\left(x_{i}\right) h_{B \sigma(j)}\left(x_{i}\right)\right)}{\sum_{i=1}^{n}\left(\frac{1}{l_{i}} \sum_{j=1}^{l_{i}} h_{A \sigma(j)}^{2}\left(x_{i}\right)\right) \sum_{i=1}^{n}\left(\frac{1}{l_{i}} \sum_{j=1}^{l_{i}} h_{B \sigma(j)}^{2}\left(x_{i}\right)\right)} .
$$

Step 7: The values are greater than averaged values of the correlation coefficients and are selected as the related criteria of energy policy and investments.

Stage 2: Compute the weights of criteria with DEMATEL.

Step 1: Linguistic evaluations are collected for the initial direct relation matrix.

Step 2: The evaluations are changed into the fuzzy numbers based on interval type-2 fuzzy sets.

Step 3: The fuzzy relation matrix is normalized with Equations (8)-(10).

$$
\begin{aligned}
& \widetilde{X}=\left[\begin{array}{ccccc}
\widetilde{x}_{11} & \widetilde{x}_{12} & \ldots & \ldots & \widetilde{x}_{1 n} \\
\widetilde{x}_{21} & \widetilde{x}_{22} & \ldots & \ldots & \widetilde{x}_{2 n} \\
\vdots & \vdots & \ddots & \ldots & \ldots \\
\vdots & \vdots & \vdots & \ddots & \vdots \\
\widetilde{x}_{n 1} & \widetilde{x}_{n 2} & \ldots & \ldots & \widetilde{x}_{n n}
\end{array}\right] \\
& \widetilde{x}_{i j}=\frac{\widetilde{z}_{i j}}{r}=\left(\frac{Z_{a_{i j}^{\prime}}}{r}, \frac{Z_{b_{i j}^{\prime}}}{r}, \frac{Z_{c_{i j}^{\prime}}}{r}, \frac{Z_{\dot{d}_{i j}}}{r} ; H_{1}\left(z_{i j}^{U}\right), H_{2}\left(z_{i j}^{U}\right)\right),\left(\frac{Z_{e_{i j}^{\prime}}}{r}, \frac{Z_{f_{i j}}}{r}, \frac{Z_{g_{i j}^{\prime}}}{r}, \frac{Z_{h_{i j}^{\prime}}}{r} ; H_{1}\left(z_{i j}^{L}\right), H_{2}\left(z_{i j}^{L}\right)\right) \\
& r=\max \left(\max _{1 \leq i \leq n} \sum_{j=1}^{n} \mathrm{Z}_{d_{i j}} \max _{1 \leq i \leq n} \sum_{j=1}^{n} \mathrm{Z}_{d_{i j}}\right)
\end{aligned}
$$

Step 4: Total influence matrix is constructed to define the impact and relation degrees by Equations (11)-(15).

$$
\begin{aligned}
& X_{a}=\left[\begin{array}{ccccc}
0 & a_{12}^{\prime} & \cdots & \cdots & a_{1 n}^{\prime} \\
a^{\prime}{ }_{21} & 0 & \cdots & \cdots & a^{\prime}{ }_{2 n} \\
\vdots & \vdots & \ddots & \cdots & \cdots \\
\vdots & \vdots & \vdots & \ddots & \vdots \\
a_{n 1}^{\prime} & a_{n 2}^{\prime} & \cdots & \cdots & 0
\end{array}\right], \ldots, X_{h}=\left[\begin{array}{ccccc}
0 & h^{\prime}{ }_{12} & \cdots & \cdots & h^{\prime}{ }_{1 n} \\
h^{\prime}{ }_{21} & 0 & \cdots & \cdots & h^{\prime}{ }_{2 n} \\
\vdots & \vdots & \ddots & \cdots & \cdots \\
\vdots & \vdots & \vdots & \ddots & \vdots \\
h^{\prime}{ }_{n 1} & h^{\prime}{ }_{n 2} & \cdots & \cdots & 0
\end{array}\right] \\
& \widetilde{T}=\lim _{k \rightarrow \infty} \widetilde{X}+\widetilde{X}^{2}+\ldots+\widetilde{X}^{k} \\
& \widetilde{T}=\left[\begin{array}{ccccc}
\widetilde{t}_{11} & \widetilde{t}_{12} & \cdots & \cdots & \widetilde{t}_{1 n} \\
\widetilde{t}_{21} & \widetilde{t}_{22} & \cdots & \cdots & \widetilde{t}_{2 n} \\
\vdots & \vdots & \ddots & \cdots & \cdots \\
\vdots & \vdots & \vdots & \ddots & \vdots \\
\widetilde{t}_{n 1} & \tilde{t}_{n 2} & \cdots & \cdots & \widetilde{t}_{n n}
\end{array}\right]
\end{aligned}
$$




$$
\begin{gathered}
\widetilde{t}_{i j}=\left(a^{\prime \prime}{ }_{i j}, b^{\prime \prime}{ }_{i j}, c^{\prime \prime}{ }_{i j}, d^{\prime \prime}{ }_{i j} ; H_{1}\left(\widetilde{t}_{i j} u\right), H_{2}\left(\widetilde{t}_{i j}{ }^{U}\right)\right),\left(e^{\prime \prime}{ }_{i j}, f^{\prime \prime}{ }_{i j}, g^{\prime \prime}{ }_{i j}, h^{\prime \prime}{ }_{i j} ; H_{1}\left(\widetilde{t}_{i j}{ }^{L}\right), H_{2}\left(\widetilde{t}_{i j}{ }^{L}\right)\right) \\
{\left[a^{\prime \prime}{ }_{i j}\right]=X_{a} \times\left(I-X_{a}\right)^{-1}, \ldots,\left[h^{\prime \prime}{ }_{i j}\right]=X_{\hat{h}} \times\left(I-X_{h}\right)^{-1}}
\end{gathered}
$$

Step 5: The matrix is defuzzified with Equations (16)-(19) $[44,45]$.

$$
\begin{gathered}
\operatorname{Def}_{T}=\frac{\frac{\left(u_{U}-l_{U}\right)+\left(\beta_{U} \times m_{1 U}-l_{U}\right)+\left(\alpha_{U} \times m_{2 U}-l_{U}\right)}{4}+l_{U}+\left[\frac{\left(u_{L}-l_{L}\right)+\left(\beta_{L} \times m_{1 L}-l_{L}\right)+\left(\alpha_{L} \times m_{2 L}-l_{L}\right)}{4}\right]}{2} \\
D e f_{T}=T=\left[t_{i j}\right]_{n \times n}, i, j=1,2, \ldots, n \\
\widetilde{D}_{i}^{d e f}=r=\left[\sum_{j=1}^{n} t_{i j}\right]_{n \times 1}=\left(r_{i}\right)_{n \times 1}=\left(r_{1}, \ldots, r_{i}, \ldots, r_{n}\right) \\
\widetilde{R}_{i}^{d e f}=y=\left[\sum_{i=1}^{n} t_{i j}\right]_{1 \times n}^{\prime}=\left(y_{j}\right)_{1 \times n}^{\prime}=\left(y_{1}, \ldots, y_{i}, \ldots, y_{n}\right)
\end{gathered}
$$

Step 6: Total values of the rows and columns are determined for weighting the criteria.

Stage 3: Rank the alternatives of renewable energy sources with TOPSIS [46,47].

Step 1: Linguistic evaluations of each alternative are collected with respect to the criteria Step 2: The interval type-2 fuzzy numbers are provided for each evaluation.

Step 3: The averaged values of the fuzzy decision matrix are defuzzified.

Step 4: The weighted values of the matrix are computed

Step 5: The values of D+ and D- are calculated as

$$
\begin{aligned}
& D_{i}^{+}=\sqrt{\sum_{i=1}^{m}\left(v_{i}-A_{i}^{+}\right)^{2}}, \\
& D_{i}^{-}=\sqrt{\sum_{i=1}^{m}\left(v_{i}-A_{i}^{-}\right)^{2}} .
\end{aligned}
$$

Step 6: The values of the closeness coefficient $C C_{i}$ are determined to rank the alternatives with Equation (22)

$$
C C_{i}=\frac{D_{i}^{-}}{D_{i}^{+}+D_{i}^{-}}
$$

Step 7: Sensitivity analysis is applied for the robustness check of the proposed model. For that, the weights of recognitive factors are changed consecutively with twelve cases for checking the coherency of provided results.

\section{An Analysis for Renewable Energy Policies and Investments}

The integrated model is proposed for evaluating the alternative energy sources for the policies and investments. For this purpose, the set of criteria is defined for energy policies and investments. Table 1 shows the eight criteria titled geography (criterion 1), returns (criterion 2), facilities (criterion 3), legislation (criterion 4), climate (criterion 4), experience (criterion 6), technological background (criterion 7), and market participants (criterion 8) based on the supported literature.

In the following step, three decision makers are appointed to provide their choices for each criterion. These experts have a minimum of ten years of experience in the renewable energy industry, and they are senior and top managers. Linguistic choices and their fuzzy numbers are defined, as seen in Table 2. 
Table 1. Proposed factors for energy policies and investments.

\begin{tabular}{|c|c|c|}
\hline Criteria & Definition & Supported Literature \\
\hline Geography (C1) & $\begin{array}{l}\text { Geographical conditions to select } \\
\text { the renewable sources }\end{array}$ & $\begin{array}{l}\text { Castillo et al. [9], Leautier [10], } \\
\text { Frantál and Prousek [11], Kumar and } \\
\text { Samuel [12], Chatterjee and Kar [13] }\end{array}$ \\
\hline Returns (C2) & $\begin{array}{l}\text { Profits and return period of energy } \\
\text { investments }\end{array}$ & $\begin{array}{l}\text { De Boeck et al. [14], Kim et al. [15], } \\
\text { Alizamir et al. [16], } \\
\text { Reboredo et al. [17], Bruno et al. [18] }\end{array}$ \\
\hline Facilities (C3) & $\begin{array}{l}\text { Ease of investment from the } \\
\text { start-up to commercialization }\end{array}$ & $\begin{array}{c}\text { Rodríguez et al. [3], Komendantova } \\
\text { and Stepanova [19], Jena et al. [20], } \\
\text { Lv and Spigarelli [21], } \\
\text { Junlakarn et al. [22] }\end{array}$ \\
\hline Legislation (C4) & $\begin{array}{l}\text { Restrictions of obligatory } \\
\text { authority and legal regulatory }\end{array}$ & $\begin{array}{l}\text { Chang et al. [23], Özkale et al. [24], } \\
\text { Young and Brans [25], } \\
\text { Morea and Poggi [26], Hua et al. [27] }\end{array}$ \\
\hline Climate (C5) & $\begin{array}{l}\text { Weather conditions effecting the } \\
\text { renewable sources }\end{array}$ & $\begin{array}{c}\text { Strantzali and Aravossis [28], } \\
\text { Chappin et al. [29], Kim et al. [15], } \\
\text { Kober et al. [30], } \\
\text { Guerrero-Liquet et al. [31] }\end{array}$ \\
\hline Experience (C6) & $\begin{array}{l}\text { Number of similar projects } \\
\text { completed by the same team }\end{array}$ & $\begin{array}{c}\text { Şener et al. [32], } \\
\text { Guerrero-Liquet et al. [31], } \\
\text { de Arce et al. [33], } \\
\text { Radomes Jr and Arango [34] }\end{array}$ \\
\hline Technological background (C7) & $\begin{array}{l}\text { Infrastructure of research and } \\
\text { development for the innovative } \\
\text { projects }\end{array}$ & $\begin{array}{c}\text { Aflaki and Netessine [35], } \\
\text { Salm et al. [36], Polzin et al. [37], } \\
\text { Lam and Law [38] }\end{array}$ \\
\hline Market participants (C8) & $\begin{array}{l}\text { Balance of supply and demand for } \\
\text { competitive energy sources }\end{array}$ & $\begin{array}{c}\text { Ritzenhofen and Spinler [39], } \\
\text { Salm and Wüstenhagen [40], } \\
\text { Uyar and Beşikci [41], } \\
\text { Bruno et al. [18] }\end{array}$ \\
\hline
\end{tabular}

Table 2. Linguistic scales and interval type 2 fuzzy numbers for the evaluations.

\begin{tabular}{ccc}
\hline Alternative Evaluations & Criterion Evaluations & Interval Type 2 Fuzzy Numbers \\
\hline Very Poor $(\mathrm{VP})$ & Very low $(\mathrm{VL})$ & {$[(0,0,0,0.1 ; 1,1),(0,0,0,0.05 ; 0.9,0.9)]$} \\
Poor $(\mathrm{P})$ & Low $(\mathrm{L})$ & {$[(0,0.1,0.1,0.3 ; 1,1)$,} \\
& & $(0.05,0.1,0.1,0.2 ; 0.9,0.9)]$ \\
Medium Poor $(\mathrm{MP})$ & {$[(0.1,0.3,0.3,0.5 ; 1,1)$,} \\
& Medium Low $(\mathrm{ML})$ & $(0.2,0.3,0.3,0.4 ; 0.9,0.9)]$ \\
Fair $(\mathrm{F})$ & & {$[(0.3,0.5,0.5,0.7 ; 1,1)$,} \\
& Medium $(\mathrm{M})$ & $(0.4,0.5,0.5,0.6 ; 0.9,0.9)]$ \\
Good $(\mathrm{G})$ & & {$[(0.5,0.7,0.7,0.9 ; 1,1)$,} \\
& Medium high $(\mathrm{MH})$ & $(0.6,0.7,0.7,0.8 ; 0.9,0.9)]$ \\
Very Good $(\mathrm{VG})$ & & {$[(0.7,0.9,0.9,1 ; 1,1)$,} \\
Best $(\mathrm{B})$ & High $(\mathrm{H})$ & $(0.8,0.9,0.9,0.95 ; 0.9,0.9)]$ \\
& Very high $(\mathrm{VH})$ & {$[(0.9,1,1,1 ; 1,1),(0.95,1,1,1 ; 0.9,0.9)]$} \\
\hline
\end{tabular}

Source: Adapted from [46] and [47].

Recognition of the energy policies and investment factors with correlation coefficients based on interval type-2 fuzzy sets

First, linguistic scores of each dimension and criterion are collected under the effect of the balanced scorecard factors. Table 3 represents the balanced scorecard-based linguistic evaluations of policy and investment factors. 
Table 3. Balanced scorecard-based linguistic decision matrix for the policy and investment factors.

\begin{tabular}{|c|c|c|c|c|c|c|c|c|c|c|c|c|}
\hline \multirow{2}{*}{ Evaluations } & \multicolumn{3}{|c|}{ Finance } & \multicolumn{3}{|c|}{ Customer } & \multicolumn{3}{|c|}{ Internal Process } & \multicolumn{3}{|c|}{ Learning and Growth } \\
\hline & DM1 & DM2 & DM3 & DM1 & DM2 & DM3 & DM1 & DM2 & DM3 & DM1 & DM2 & DM3 \\
\hline Policy & $\mathrm{MH}$ & M & ML & M & ML & ML & M & ML & ML & M & M & $\mathrm{M}$ \\
\hline Investment & $\mathrm{VH}$ & $\mathrm{H}$ & VH & $\mathrm{H}$ & VH & VH & $\mathrm{H}$ & $\mathrm{MH}$ & $\mathrm{MH}$ & $\mathrm{H}$ & $\mathrm{H}$ & $\mathrm{MH}$ \\
\hline
\end{tabular}

To compute the correlation coefficients between the dimensions and criteria based on the balanced scorecard factors, the evaluations of the criteria are presented with respect to the perspectives of the balanced scorecard, and the results are illustrated in Table 4 .

Table 4. Balanced scorecard-based linguistic decision matrix for the criteria.

\begin{tabular}{cccccccccccccc}
\hline \multirow{2}{*}{ Evaluations } & \multicolumn{3}{c}{ Finance } & \multicolumn{4}{c}{ Customer } & \multicolumn{3}{c}{ Internal Process } & \multicolumn{2}{c}{ Learning and Growth } \\
\cline { 2 - 12 } & DM1 & DM2 & DM3 & DM1 & DM2 & DM3 & DM1 & DM2 & DM3 & DM1 & DM2 & DM3 \\
\hline Geography (C1) & M & MH & MH & H & H & VH & M & M & MH & M & M & M \\
Returns (C2) & VH & H & VH & H & M & MH & M & MH & MH & M & MH & MH \\
Facilities (C3) & H & MH & H & VH & VH & H & H & MH & MH & VH & H & MH \\
Legislation (C4) & M & M & M & M & MH & M & M & MH & MH & M & MH & MH \\
Climate (C5) & M & ML & M & MH & MH & MH & MH & M & M & M & ML & M \\
Experience (C6) & MH & H & MH & MH & VH & H & H & VH & VH & VH & VH & H \\
Technology (C7) & H & MH & MH & MH & H & H & MH & H & MH & VH & H & MH \\
Market potential (C8) & H & H & VH & VH & VH & H & M & M & ML & H & MH & H \\
\hline
\end{tabular}

Linguistic evaluations of each dimension and criteria are converted into the interval type-2 fuzzy numbers. And then, the fuzzy numbers are defuzzified by Equations (17)-(20). Table 5 presents the defuzzified values of the balanced scorecard-based decision matrix.

Table 5. Defuzzified values of the balanced scorecard-based decision matrix.

\begin{tabular}{ccccccccc}
\hline Factors/Criteria & C1 & C2 & C3 & C4 & C5 & C6 & C7 & C8 \\
\hline Policy & 190.2 & 203.0 & 220.9 & 179.8 & 171.4 & 225.9 & 213.5 & 211.8 \\
Investment & 274.4 & 290.4 & 316.3 & 256.4 & 246.5 & 322.2 & 304.8 & 303.8 \\
\hline
\end{tabular}

The values of correlation coefficients are calculated by Equations (21)-(23). Table 6 shows the results, and the mean value of the correlation coefficients is defined as a threshold value (0.995); the scores higher than the threshold means that they are defined by the related factor.

Table 6. The values of correlation coefficients (mean value: 0.995).

\begin{tabular}{ccccccccc}
\hline Factors/Criteria & C1 & C2 & C3 & C4 & C5 & C6 & C7 & C8 \\
\hline Policy & 0.985 & 0.996 & 0.996 & 0.996 & 0.988 & 0.995 & 0.998 & 0.991 \\
Investment & 0.995 & 0.997 & 0.999 & 0.995 & 0.995 & 0.994 & 0.998 & 0.995 \\
\hline
\end{tabular}

Table 7 defines the determinants for the energy policies and investments. According to the results, the policy factor includes the returns (criterion 2), facilities (criterion 3), legislation (criterion 4), experience (criterion 6), and technology (criterion 7). The investment factor has geography (criterion 1), returns (criterion 2), facilities (criterion 3), legislation (criterion 4), climate (criterion 5), technology (criterion 7), and market potential (criterion 8). 
Table 7. Recognitive determinants for the energy policies and investments.

\begin{tabular}{cc}
\hline Factors & Selected Criteria \\
\hline \multirow{3}{*}{ Policy } & Returns (C2) \\
& Facilities (C3) \\
& Legislation (C4) \\
& Experience (C6) \\
& Technology (C7) \\
\hline & Geography (C1) \\
Investments & Returns (C2) \\
& Facilities (C3) \\
& Legislation (C4) \\
& Climate (C5) \\
& Technology (C7) \\
& Market potential (C8)) \\
\hline
\end{tabular}

Determining the importance of the criteria with DEMATEL based on interval type-2 fuzzy sets

The second stage of the proposed model is to weight the selected criteria for each factor. Accordingly, relation matrices for policy and investment factors are constructed to measure the interval type-2 fuzzy sets-based analysis with DEMATEL. For that, linguistic evaluations for the criteria are obtained, and the scores are shown in Tables 8 and 9, respectively.

Table 8. Linguistic evaluations for the policy factors.

\begin{tabular}{|c|c|c|c|c|c|c|c|c|c|c|c|c|c|c|c|}
\hline \multirow{2}{*}{ Evaluations } & \multicolumn{3}{|c|}{ Returns (C2) } & \multicolumn{3}{|c|}{ Facilities (C3) } & \multicolumn{3}{|c|}{ Legislation (C4) } & \multicolumn{3}{|c|}{ Experience (C6) } & \multicolumn{3}{|c|}{ Technology (C7) } \\
\hline & DM1 & DM2 & DM3 & DM1 & DM2 & DM3 & DM1 & DM2 & DM3 & DM1 & DM2 & DM3 & DM1 & DM2 & DM3 \\
\hline & - & - & - & $\mathrm{H}$ & MH & MH & MH & MH & MH & $\mathrm{MH}$ & $\mathrm{H}$ & M & $\mathrm{VH}$ & $\mathrm{H}$ & $\mathrm{H}$ \\
\hline Facilit & $\mathrm{VH}$ & $\mathrm{H}$ & VH & - & - & - & $\mathrm{M}$ & M & ML & MH & MH & $\mathrm{H}$ & MH & $\mathrm{H}$ & $\mathrm{H}$ \\
\hline Legislation (C4) & MH & ML & $\mathrm{M}$ & M & $\mathrm{M}$ & M & - & - & - & $\mathrm{M}$ & ML & M & ML & ML & ML \\
\hline Experience (C6) & MH & MH & $\mathrm{M}$ & M & MH & $\mathrm{H}$ & ML & $\mathrm{M}$ & ML & - & - & - & MH & ML & $\mathrm{M}$ \\
\hline Technology (C7) & $\mathrm{H}$ & $\mathrm{H}$ & $\mathrm{H}$ & $\mathrm{H}$ & VH & $\mathrm{H}$ & $\mathrm{M}$ & ML & ML & MH & MH & M & - & - & - \\
\hline
\end{tabular}

Table 10 determines the local and global weights of criteria for each factor by using Equations (24)-(35). In the policy factor, returns (criterion 2) is the most important criterion as legislation (criterion 4) has the weakest importance among the criterion set. In the investment factor, technology (criterion 7) is the most important, relatively, whereas legislation (criterion 4) has the last degree among the criteria of investment.

These results are also illustrated in detail in Figure 1.

The final stage of the analysis is to rank the alternative energy sources with IT2 fuzzy TOPSIS. Initially, a linguistic decision matrix is constructed, as seen in Table 11.

The linguistic matrix is reconstructed as a fuzzy decision matrix based on interval type-2 fuzzy numbers, and, then, the average scores obtained from the decision makers are defuzzified with Equations (17)-(20). The results are represented in Table 12.

The following step continues with the weighted decision matrix. For that, the weight results from IT2 fuzzy DEMATEL are used for the weighted matrix. The results are given on Table 13.

The values of $\mathrm{D}+$ and $\mathrm{D}-$ are calculated to find out the closeness coefficient scores for each alternative with Equations (36)-(38). The results are shown in Table 14. 
Table 9. Linguistic evaluations for the investment factors.

\begin{tabular}{|c|c|c|c|c|c|c|c|c|c|c|c|c|c|c|c|c|c|c|c|c|c|}
\hline \multirow{2}{*}{ Evaluations } & \multicolumn{3}{|c|}{ Geography (C1) } & \multicolumn{3}{|c|}{ Returns (C2) } & \multicolumn{3}{|c|}{ Facilities (C3) } & \multicolumn{3}{|c|}{ Legislation (C4) } & \multicolumn{3}{|c|}{ Climate (C5) } & \multicolumn{3}{|c|}{ Technology (C7) } & \multicolumn{3}{|c|}{ Market potential (C8) } \\
\hline & DM1 & DM2 & DM3 & DM1 & DM1 & DM2 & DM3 & DM1 & DM2 & DM3 & DM1 & DM2 & DM1 & DM2 & DM3 & DM1 & DM2 & DM3 & DM1 & DM2 & DM3 \\
\hline Geography (C1) & - & - & - & $\mathrm{MH}$ & $\mathrm{MH}$ & $\mathrm{MH}$ & $\mathrm{H}$ & $\mathrm{MH}$ & $\mathrm{MH}$ & $\mathrm{H}$ & $\mathrm{MH}$ & $\mathrm{MH}$ & MH & $\mathrm{MH}$ & $\mathrm{H}$ & $\mathrm{L}$ & ML & ML & ML & M & $\mathrm{M}$ \\
\hline Returns (C2) & ML & $\mathrm{M}$ & $\mathrm{L}$ & - & ML & ML & ML & ML & ML & ML & ML & ML & ML & ML & ML & $\mathrm{MH}$ & $\mathrm{H}$ & $\mathrm{VH}$ & $\mathrm{H}$ & $\mathrm{MH}$ & $\mathrm{MH}$ \\
\hline Facilities (C3) & $\mathrm{L}$ & ML & ML & $\mathrm{M}$ & ML & ML & $\mathrm{M}$ & ML & ML & $\mathrm{M}$ & ML & ML & ML & ML & $\mathrm{M}$ & $\mathrm{H}$ & $\mathrm{VH}$ & $\mathrm{H}$ & $\mathrm{VH}$ & $\mathrm{H}$ & $\mathrm{H}$ \\
\hline Legislation (C4) & $\mathrm{H}$ & MH & $\mathrm{MH}$ & $\mathrm{M}$ & ML & ML & $\mathrm{L}$ & ML & ML & $\mathrm{L}$ & ML & ML & ML & ML & $\mathrm{L}$ & M & ML & $\mathrm{M}$ & ML & M & M \\
\hline Climate (C5) & $\mathrm{H}$ & MH & $\mathrm{H}$ & ML & - & - & - & - & - & - & - & - & - & - & - & $\mathrm{M}$ & ML & $\mathrm{M}$ & ML & ML & $\mathrm{M}$ \\
\hline Technology (C7) & ML & $\mathrm{L}$ & ML & $\mathrm{VH}$ & MH & MH & $\mathrm{M}$ & MH & $\mathrm{MH}$ & $\mathrm{M}$ & MH & MH & $\mathrm{MH}$ & $\mathrm{MH}$ & $\mathrm{M}$ & - & - & - & $\mathrm{VH}$ & $\mathrm{VH}$ & $\mathrm{H}$ \\
\hline Market potential (C8)) & ML & M & $\mathrm{M}$ & $\mathrm{VH}$ & $\mathrm{M}$ & ML & ML & $\mathrm{M}$ & ML & ML & $\mathrm{M}$ & ML & $\mathrm{M}$ & ML & ML & $\mathrm{H}$ & $\mathrm{H}$ & MH & - & - & - \\
\hline
\end{tabular}


Table 10. Weights of policy and investment factors.

\begin{tabular}{cccc}
\hline Factors & Criteria & Local Weights & Global Weights \\
\hline \multirow{4}{*}{ Policy } & Returns (C2) & 0.227 & 0.113 \\
& Facilities (C3) & 0.222 & 0.111 \\
& Legislation (C4) & 0.152 & 0.076 \\
Experience (C6) & 0.190 & 0.095 \\
Technology (C7) & 0.210 & 0.105 \\
\hline \multirow{5}{*}{ Investment } & Geography (C1) & 0.126 & 0.063 \\
& Returns (C2) & 0.145 & 0.072 \\
& Facilities (C3) & 0.156 & 0.078 \\
& Legislation (C4) & 0.118 & 0.059 \\
& Climate (C5) & 0.123 & 0.061 \\
& Technology (C7) & 0.168 & 0.084 \\
& Market potential (C8) & 0.164 & 0.082 \\
\hline
\end{tabular}

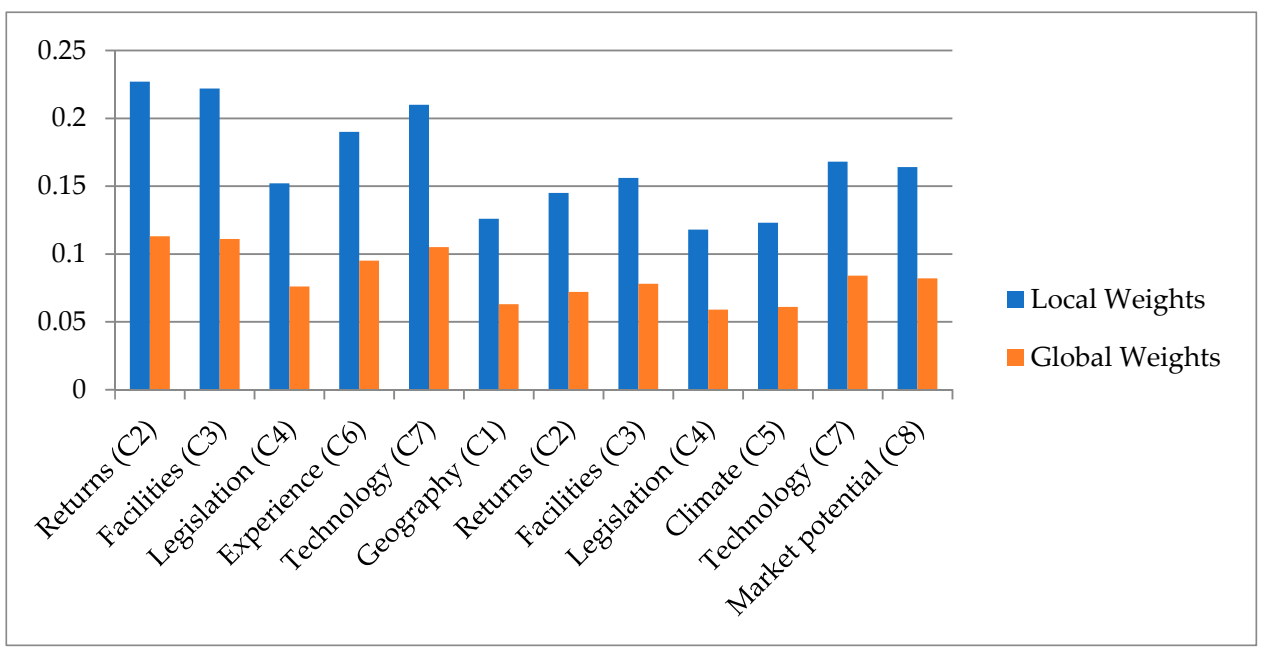

Figure 1. Local and global weights of factors.

Table 11. Linguistic decision matrix.

\begin{tabular}{|c|c|c|c|c|c|c|c|c|c|c|c|c|c|c|c|}
\hline \multirow{2}{*}{ Evaluations } & \multicolumn{3}{|c|}{ Biomass (A1) } & \multicolumn{3}{|c|}{ Hydropower (A2) } & \multicolumn{3}{|c|}{ Geothermal (A3) } & \multicolumn{3}{|c|}{ Wind (A4) } & \multicolumn{3}{|c|}{ Solar (A5) } \\
\hline & DM1 & DM2 & DM3 & DM1 & DM2 & DM3 & DM1 & DM2 & DM3 & DM1 & DM2 & DM3 & DM1 & DM2 & DM3 \\
\hline \multicolumn{16}{|c|}{ Investment-based } \\
\hline Geography (C1) & G & $\mathrm{F}$ & $\mathrm{F}$ & B & VG & G & G & VG & B & B & VG & VG & G & VG & G \\
\hline Returns (C2) & B & VG & VG & VG & VG & VG & VG & G & G & VG & VG & B & VG & VG & B \\
\hline Facilities (C3) & G & $\mathrm{F}$ & G & G & $\mathrm{F}$ & $\mathrm{F}$ & G & $\mathrm{F}$ & G & G & VG & G & G & G & VG \\
\hline Legislation (C4) & G & G & G & VG & G & G & VG & G & G & G & G & G & G & $\mathrm{F}$ & G \\
\hline Climate (C5) & $\mathrm{F}$ & G & $\mathrm{FP}$ & G & G & VG & G & G & G & VG & B & G & VGV & G & G \\
\hline Technology (C7) & VG & G & VG & G & VG & G & G & G & VG & B & VG & VG & B & VG & VG \\
\hline Market potential (C8) & VG & G & G & G & $\mathrm{F}$ & G & $\mathrm{F}$ & $\mathrm{F}$ & G & VG & G & VG & B & VG & VG \\
\hline \multicolumn{16}{|c|}{ Policy-based } \\
\hline Returns (C2) & VG & G & G & VG & VG & VG & G & VG & VG & VG & VG & VG & B & VG & VG \\
\hline Facilities (C3) & VG & VG & VG & VG & B & VG & VG & G & VG & VG & G & VG & VG & VG & VG \\
\hline Legislation (C4) & G & VG & VG & VG & VG & B & B & VG & VG & VG & B & VG & VG & B & B \\
\hline Experience (C6) & B & B & VG & B & VG & B & B & B & B & VG & B & B & VG & VG & G \\
\hline Technology (C7) & B & VG & VG & B & VG & B & B & B & B & VG & G & B & VG & B & VG \\
\hline
\end{tabular}


Table 12. Defuzzified decision matrix.

\begin{tabular}{cccccc}
\hline Alternatives/Criteria & Biomass (A1) & Hydropower (A2) & Geothermal (A3) & Wind (A4) & Solar (A5) \\
\hline \multicolumn{5}{c}{ Investment-based } \\
\hline Geography (C1) & 7.07 & 8.86 & 8.86 & 9.25 & 8.26 \\
Returns (C2) & 9.25 & 9.03 & 8.26 & 9.25 & 9.25 \\
Facilities (C3) & 7.47 & 7.07 & 7.47 & 8.26 & 8.26 \\
Legislation (C4) & 7.87 & 8.26 & 8.26 & 7.87 & 7.47 \\
Climate (C5) & 6.67 & 8.26 & 7.87 & 8.86 & 6.51 \\
Technology (C7) & 8.64 & 8.26 & 8.26 & 9.25 & 9.25 \\
Market potential (C8) & 8.26 & 7.47 & 7.07 & 8.64 & 9.25 \\
\hline & & Policy-based & & \\
\hline Returns (C2) & 8.26 & 9.03 & 8.64 & 9.03 & 9.25 \\
Facilities (C3) & 9.03 & 9.25 & 8.64 & 8.64 & 9.03 \\
Legislation (C4) & 8.64 & 9.25 & 9.25 & 9.25 & 9.47 \\
Experience (C6) & 9.47 & 9.47 & 9.69 & 9.47 & 8.64 \\
Technology (C7) & 9.25 & 9.47 & 9.69 & 8.86 & 9.25 \\
\hline
\end{tabular}

Table 13. Weighted decision matrix.

\begin{tabular}{cccccc}
\hline Alternatives/Criteria & Biomass (A1) & Hydropower (A2) & Geothermal (A3) & Wind (A4) & Solar (A5) \\
\hline \multicolumn{7}{c}{ Investment-based } \\
\hline Geography (C1) & 0.45 & 0.56 & 0.56 & 0.58 & 0.52 \\
Returns (C2) & 0.67 & 0.65 & 0.60 & 0.67 & 0.67 \\
Facilities (C3) & 0.58 & 0.55 & 0.58 & 0.64 & 0.64 \\
Legislation (C4) & 0.47 & 0.49 & 0.49 & 0.47 & 0.44 \\
Climate (C5) & 0.41 & 0.51 & 0.48 & 0.55 & 0.40 \\
Technology (C7) & 0.73 & 0.70 & 0.70 & 0.78 & 0.78 \\
Market potential (C8) & 0.68 & 0.61 & 0.71 & 0.76 \\
\hline & & Policy-based & & 1.05 \\
Returns (C2) & 0.94 & 1.02 & 0.98 & 1.02 & 1.00 \\
Facilities (C3) & 1.00 & 1.03 & 0.96 & 0.96 \\
Legislation (C4) & 0.66 & 0.70 & 0.70 & 0.70 & 0.72 \\
Experience (C6) & 0.90 & 0.90 & 1.02 & 0.90 & 0.82 \\
Technology (C7) & 0.97 & 0.99 & 0.93 & 0.97 \\
\hline
\end{tabular}

Table 14. Performance results of renewable energy investment alternatives.

\begin{tabular}{ccccc}
\hline Results & D+ & D- & & Ranking \\
\hline Biomass (A1) & 0.265 & 0.164 & 0.382 & 5 \\
Hydropower (A2) & 0.202 & 0.235 & 0.537 & 3 \\
Geothermal (A3) & 0.248 & 0.210 & 0.459 & 4 \\
Wind (A4) & 0.128 & 0.305 & 0.705 & 1 \\
Solar (A5) & 0.199 & 0.279 & 0.584 & 2 \\
\hline
\end{tabular}

The performance results of renewable energy investment alternatives are ranked as wind (alternative 4), solar (alternative 5), hydropower (alternative 2), geothermal (alternative 3), and biomass (alternative 1), respectively. The results demonstrate that wind is the best alternative among the renewable sources, while biomass has the worst rank in the alternative set. This situation is also depicted in Figure 2 accordingly. In this figure, the results of closeness coefficients for each alternative are illustrated to rank the alternatives. 


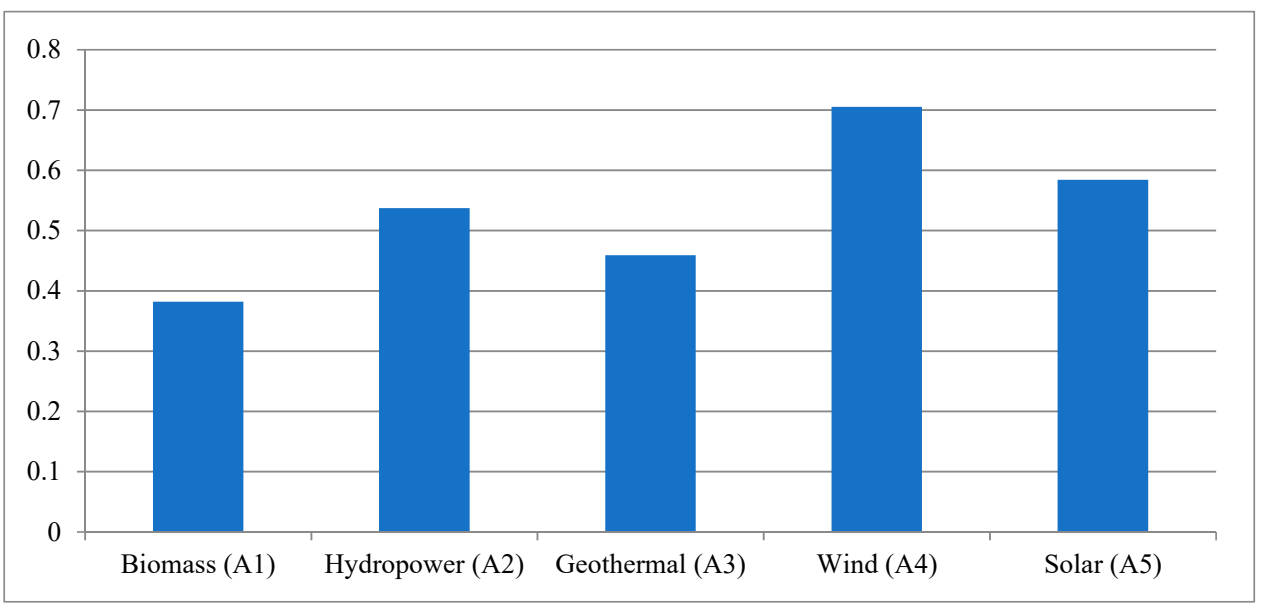

Figure 2. Performance results of renewable energy alternatives.

At the final stage, a sensitivity analysis is applied for checking the results of the proposed model, as shown in step 7 of the proposed method. The sensitivity analysis is mainly made to correct the effectiveness of the model. The analysis aims to confirm the results of the integrated model by the cases. For this purpose, the sensitivity analysis is used to determine whether there is an effect on the ranking as a result of changing the weight of each criterion. In this study, 12 cases are illustrated by changing the weights of criteria consecutively, and the results are compared to understand how they are coherent by the cases. Table 15 represents the ranking results for 12 cases, respectively.

Table 15. Sensitivity analysis for ranking results.

\begin{tabular}{cccccc}
\hline Cases/Alternatives & A1 & A2 & A3 & A4 & A5 \\
\hline Case 1 & 5 & 3 & 4 & 1 & 2 \\
Case 2 & 5 & 3 & 4 & 1 & 2 \\
Case 3 & 5 & 2 & 3 & 1 & 4 \\
Case 4 & 5 & 2 & 4 & 1 & 3 \\
Case 5 & 5 & 2 & 4 & 1 & 3 \\
Case 6 & 5 & 2 & 3 & 1 & 4 \\
Case 7 & 5 & 2 & 4 & 1 & 3 \\
Case 8 & 5 & 3 & 4 & 1 & 2 \\
Case 9 & 5 & 2 & 4 & 1 & 3 \\
Case 10 & 5 & 2 & 4 & 1 & 3 \\
Case 11 & 5 & 3 & 4 & 1 & 2 \\
Case 12 & 5 & 3 & 4 & 1 & 2 \\
\hline
\end{tabular}

Table 15 shows that wind (alternative 4 ) is ranked in the first order while biomass (alternative 1) has the last rank for 12 cases. Additionally, the overall results are almost the same for all cases. So, the results of the sensitivity analysis demonstrate that ranking the results of renewable energy investment alternatives with the proposed model are coherent for each case. When the results obtained are compared, the overall ranking results consistently remain in the same order even if the weight results change in order. As a result, it is concluded that the model we proposed is consistent with the analysis model for weight and the method used for ranking.

\section{Discussion}

The investment and policy-based multidimensional analysis is one of important debate for renewable investment projects. Especially, the selection of best identifying factors is also a prominent factor for finding valuable projects. So, the balanced scorecard approach that defines finance, customer, organization, and external factors was used for constructing the policy and investment-based factors 
in a multidimensional manner, and the correlation coefficient technique was applied to categorize the proposed factors of project evaluation properly. So, the policy recommendations for the renewable energy projects could be provided based on the literature review and analysis results.

This study tried to evaluate the energy policies and investments in renewable energy resources. Within this framework, developing energy policy and investing in energy are defined as two different factors for renewable energy. Moreover, eight different criteria were also selected by doing a detailed literature review. In this study, an extension of fuzzy sets, titled the interval type-2 fuzzy set, was used for providing more comprehensive and coherent results under complex real-world problems. With the help of a correlation coefficient based on interval type- 2 fuzzy sets, these criteria were evaluated. It is concluded that five criteria have a relationship with policy factors, while seven criteria are related to the investment factor. Another important point is that the criteria of returns, facilities, legislation, and technology are classified in both policy and investment factors.

The fuzzy DEMATEL approach based on interval type-2 fuzzy sets were used to weight these criteria. And also, the performance evaluation of renewable energy investment alternatives was made with the TOPSIS approach based on interval type-2 fuzzy sets. According to the results, it is determined that policy returns, policy facilities, and policy technology are the most important criteria. In addition to this situation, ranking results of renewable energy investment alternatives demonstrate that wind is the most significant renewable energy investment alternative.

\section{Conclusions}

While considering the results, it is understood that the profits and return period of energy investments play a key role in policy generation for renewable energy. In addition, the ease of investment from the start-up to commercialization and research and development infrastructure for the innovative projects are also essential issues for this purpose. Another important recommendation is that there should be government supports for wind energy to attract the attention of the investors. For example, the design and production of wind turbines are multi-stage and complex. In this circumstance, governments should provide expert analysis to assist in the design of these complex turbines. Also, the production of large-scale generators and power electronic equipment is essential for producing large-scale wind turbines. For this situation, a loan could be given to the investors to obtain these generators and equipment.

Additionally, significant locations should be defined, which are appropriate for wind energy. For this purpose, a detailed analysis should be performed by employing significant experts in this area. Another important issue for this condition is that these supports should be provided for both onshore and offshore wind power plants. Onshore wind power plants have lower costs so that it is much easier to attract the attention of investors. However, it can be possible to generate more energy by making investments in offshore wind power plants. Thus, because of the high operation cost problem, governments should provide loans and tax incentives to the offshore wind powerplant investors.

The findings also show that solar energy is ranked second among all renewable energy investment alternatives. In this context, firstly, governments could provide some financial support to the investors in the solar energy investment process. For example, the value-added tax exemption and customs tax exemption will provide a significant financial contribution to the mentioned investors in this process. In addition to the aforementioned issues, the government's guarantee of purchasing energy from solar energy could be an important incentive as well. There are many factors that investors should pay attention to in order to build a solar power plant. For example, the design of the steel construction infrastructure of solar panels and the design and distance of the power transmission line are very important. As can be seen, the investment process for solar panels is very complex. This may lead to a decrease in the investor's interest in this area. Therefore, the government should train prospective investors to make this complex process more understandable. On the other hand, governments should also support these projects by providing qualified personnel in this area. These supports should be provided for both solar power stations and water heating systems. Solar power stations play a very 
significant role in electricity generations. However, there are different types of solar power stations. Hence, governments should lead the potential investors to select the most appropriate solar power station for them. Furthermore, heating water with solar energy has an important influence on cost cutting. Thus, these supports should be developed for these purposes.

A limitation of the study is in understanding the best renewable energy alternative sources with the criteria of energy investment and policies in a global context. Thus, the results of this study could be generalized for the best energy location selection for the policy makers and foreign investors. Another important limitation of this study is that the public support and social and environmental aspects have not been considered as criteria. Because social, cultural, and environmental factors may be effective on the decisions of the policy makers, these issues can be considered in a new study. Additionally, the method could be widened by using different approaches to multicriteria decision making models, such as MOORA and ANP. Furthermore, a cross country analysis can be performed related to this topic in future studies.

Author Contributions: All authors contributed equally to this paper.

Funding: This research was funded by the National Natural Science Foundation of China, grant number [71774130], and the Foundation of Shaanxi Provincial University Philosophy and Social Science Key Research Base, grant number [19JZ055].

Acknowledgments: This research was funded by the National Natural Science Foundation of China, grant number [71774130], and the Foundation of Shaanxi Provincial University Philosophy and Social Science Key Research Base, grant number [19JZ055].

Conflicts of Interest: The authors declare no conflict of interest.

\section{References}

1. Dinçer, H.; Yüksel, S. Multidimensional evaluation of global investments on the renewable energy with the integrated fuzzy decision-making model under the hesitancy. Int. J. Energy Res. 2019, 43, 1775-1784. [CrossRef]

2. Kim, K.; Jeong, H.; Ha, S.; Bang, S.; Bae, D.H.; Kim, H. Investment timing decisions in hydropower adaptation projects using climate scenarios: A case study of South Korea. J. Clean. Prod. 2017, 142, 1827-1836. [CrossRef]

3. Rodríguez, M.C.; Haščič, I.; Johnstone, N.; Silva, J.; Ferey, A. Renewable energy policies and private sector investment: Evidence from financial microdata. Environ. Resour. Econ. 2015, 62, 163-188. [CrossRef]

4. Dinçer, H.; Yüksel, S.; Martínez, L. Analysis of Balanced Scorecard-based SERVQUAL Criteria based on Hesitant Decision-making Approaches. Comput. Ind. Eng. 2019, 131, 1-12. [CrossRef]

5. Yazdi, M.; Nedjati, A.; Zarei, E.; Abbassi, R. A novel extension of DEMATEL approach for probabilistic safety analysis in process systems. Saf. Sci. 2020, 121, 119-136. [CrossRef]

6. Liu, Y.; Lin, R.; Ren, J. Fuzzy multicriteria decision making on ranking the biofuels production pathways. In Biofuels for a More Sustainable Future; Elsevier: Amsterdam, The Nertherlands, 2020; pp. 317-335.

7. Parveen, N.; Kamble, P.N. Decision-Making Problem Using Fuzzy TOPSIS Method with Hexagonal Fuzzy Number. In Computing in Engineering and Technology; Springer: Singapore, 2020; pp. 421-430.

8. Zeng, S.; Chen, S.M.; Fan, K.Y. Interval-valued intuitionistic fuzzy multiple attribute decision making based on nonlinear programming methodology and TOPSIS method. Inf. Sci. 2020, 506, 424-442. [CrossRef]

9. Castillo, C.P.; e Silva, F.B.; Lavalle, C. An assessment of the regional potential for solar power generation in EU-28. Energy Policy 2016, 88, 86-99. [CrossRef]

10. Leautier, F.A. Can using geographical factors leverage private equity to deliver sustainable development results? Afr. Geogr. Rev. 2017, 36, 61-84. [CrossRef]

11. Frantál, B.; Prousek, A. It's not right, but we do it. Exploring why and how Czech farmers become renewable energy producers. Biomass Bioenergy 2016, 87, 26-34. [CrossRef]

12. Kumar, M.; Samuel, C. Selection of best renewable energy source by using VIKOR method. Technol. Econ. Smart Grids Sustain. Energy 2017, 2, 8. [CrossRef]

13. Chatterjee, K.; Kar, S. A multi-criteria decision making for renewable energy selection using Z-numbers in uncertain environment. Technol. Econ. Dev. Econ. 2018, 24, 739-764. [CrossRef] 
14. De Boeck, L.; Van Asch, S.; De Bruecker, P.; Audenaert, A. Comparison of support policies for residential photovoltaic systems in the major EU markets through investment profitability. Renew. Energy 2016, 87, 42-53. [CrossRef]

15. Kim, K.; Park, H.; Kim, H. Real options analysis for renewable energy investment decisions in developing countries. Renew. Sustain. Energy Rev. 2017, 75, 918-926. [CrossRef]

16. Alizamir, S.; de Véricourt, F.; Sun, P. Efficient feed-in-tariff policies for renewable energy technologies. Oper. Res. 2016, 64, 52-66. [CrossRef]

17. Reboredo, J.C.; Rivera-Castro, M.A.; Ugolini, A. Wavelet-based test of co-movement and causality between oil and renewable energy stock prices. Energy Econ. 2017, 61, 241-252. [CrossRef]

18. Bruno, S.; Ahmed, S.; Shapiro, A.; Street, A. Risk neutral and risk averse approaches to multistage renewable investment planning under uncertainty. Eur. J. Oper. Res. 2016, 250, 979-989. [CrossRef]

19. Komendantova, N.; Stepanova, A. Impacts of risk perceptions on foreign direct investment in energy generation and transmission projects in Russia. Energy Syst. Res. 2018, 44-50. [CrossRef]

20. Jena, L.P.; Meattle, C.; Shrimali, G. Getting to India's Renewable Energy Targets: A Business Case for Institutional Investment; CPI Report: San Francisco CA, USA, March 2018.

21. Lv, P.; Spigarelli, F. The integration of Chinese and European renewable energy markets: The role of Chinese foreign direct investments. Energy Policy 2015, 81, 14-26. [CrossRef]

22. Junlakarn, S.; Wangjiraniran, W.; Phadungsri, D. Opportunities of power generation investment in ASEAN through assessing market attractiveness. Energy Procedia 2017, 142, 2831-2837. [CrossRef]

23. Chang, Y.; Fang, Z.; Li, Y. Renewable energy policies in promoting financing and investment among the East Asia Summit countries: Quantitative assessment and policy implications. Energy Policy 2016, 95, 427-436. [CrossRef]

24. Özkale, C.; Celik, C.; Turkmen, A.C.; Cakmaz, E.S. Decision analysis application intended for selection of a power plant running on renewable energy sources. Renew. Sustain. Energy Rev. 2017, 70, 1011-1021. [CrossRef]

25. Young, J.; Brans, M. Analysis of factors affecting a shift in a local energy system towards $100 \%$ renewable energy community. J. Clean. Prod. 2017, 169, 117-124. [CrossRef]

26. Morea, D.; Poggi, L.A. Islamic finance and renewable energy: An innovative model for the sustainability of investments. In Proceedings of the 2016 AEIT International Annual Conference (AEIT), Capri, Italy, 5-7 October 2016; IEEE: Capri, Italy, 2016; pp. 1-7.

27. Hua, Y.; Oliphant, M.; Hu, E.J. Development of renewable energy in Australia and China: A comparison of policies and status. Renew. Energy 2016, 85, 1044-1051. [CrossRef]

28. Strantzali, E.; Aravossis, K. Decision making in renewable energy investments: A review. Renew. Sustain. Energy Rev. 2016, 55, 885-898. [CrossRef]

29. Chappin, E.J.; de Vries, L.J.; Richstein, J.C.; Bhagwat, P.; Iychettira, K.; Khan, S. Simulating climate and energy policy with agent-based modelling: The Energy Modelling Laboratory (EMLab). Environ. Model. Softw. 2017, 96, 421-431. [CrossRef]

30. Kober, T.; Falzon, J.; van der Zwaan, B.; Calvin, K.; Kanudia, A.; Kitous, A.; Labriet, M. A multi-model study of energy supply investments in Latin America under climate control policy. Energy Econ. 2016, 56, 543-551. [CrossRef]

31. Guerrero-Liquet, G.; Sánchez-Lozano, J.; García-Cascales, M.; Lamata, M.; Verdegay, J. Decision-making for risk management in sustainable renewable energy facilities: A case study in the Dominican Republic. Sustainability 2016, 8, 455. [CrossRef]

32. Şener, S..E.C.; Sharp, J.L.; Anctil, A. Factors impacting diverging paths of renewable energy: A review. Renew. Sustain. Energy Rev. 2018, 81, 2335-2342. [CrossRef]

33. De Arce, M.P.; Sauma, E.; Contreras, J. Renewable energy policy performance in reducing $\mathrm{CO}_{2}$ emissions. Energy Econ. 2016, 54, 272-280. [CrossRef]

34. Radomes, A.A., Jr.; Arango, S. Renewable energy technology diffusion: An analysis of photovoltaic-system support schemes in Medellín, Colombia. J. Clean. Prod. 2015, 92, 152-161. [CrossRef]

35. Aflaki, S.; Netessine, S. Strategic investment in renewable energy sources: The effect of supply intermittency. Manuf. Serv. Oper. Manag. 2017, 19, 489-507. [CrossRef]

36. Salm, S.; Hille, S.L.; Wüstenhagen, R. What are retail investors' risk-return preferences towards renewable energy projects? A choice experiment in Germany. Energy Policy 2016, 97, 310-320. [CrossRef] 
37. Polzin, F.; Migendt, M.; Täube, F.A.; von Flotow, P. Public policy influence on renewable energy investments-A panel data study across OECD countries. Energy Policy 2015, 80, 98-111. [CrossRef]

38. Lam, P.T.; Law, A.O. Crowdfunding for renewable and sustainable energy projects: An exploratory case study approach. Renew. Sustain. Energy Rev. 2016, 60, 11-20. [CrossRef]

39. Ritzenhofen, I.; Spinler, S. Optimal design of feed-in-tariffs to stimulate renewable energy investments under regulatory uncertainty-A real options analysis. Energy Econ. 2016, 53, 76-89. [CrossRef]

40. Salm, S.; Wüstenhagen, R. Dream team or strange bedfellows? Complementarities and differences between incumbent energy companies and institutional investors in Swiss hydropower. Energy Policy 2018, 121, 476-487. [CrossRef]

41. Uyar, T.S.; Beşikci, D. Integration of hydrogen energy systems into renewable energy systems for better design of 100\% renewable energy communities. Int. J. Hydrog. Energy 2017, 42, 2453-2456. [CrossRef]

42. Si, S.L.; You, X.Y.; Liu, H.C.; Zhang, P. DEMATEL technique: A systematic review of the state-of-the-art literature on methodologies and applications. Math. Probl. Eng. 2018, 2018, 1-33. [CrossRef]

43. Dinçer, H.; Yüksel, S.; Korsakienè, R.; Raišienė, A.G.; Bilan, Y. IT2 Hybrid Decision-Making Approach to Performance Measurement of Internationalized Firms in the Baltic States. Sustainability 2019, 11, 296. [CrossRef]

44. Yüksel, S.; Dinçer, H.; Meral, Y. Financial Analysis of International Energy Trade: A Strategic Outlook for EU-15. Energies 2019, 12, 431. [CrossRef]

45. Dincer, H.; Yuksel, S. IT2-based Fuzzy Hybrid Decision Making Approach to Soft Computing. IEEE Access 2019, 7, 15932-15944. [CrossRef]

46. Baykasoğlu, A.; Gölcük, İ. Development of an interval type-2 fuzzy sets based hierarchical MADM model by combining DEMATEL and TOPSIS. Expert Syst. Appl. 2017, 70, 37-51. [CrossRef]

47. Kahraman, C.; Öztayşi, B.; Sarı, İ.U.; Turanoğlu, E. Fuzzy analytic hierarchy process with interval type-2 fuzzy sets. Knowl. Based Syst. 2014, 59, 48-57. [CrossRef]

(C) 2019 by the authors. Licensee MDPI, Basel, Switzerland. This article is an open access article distributed under the terms and conditions of the Creative Commons Attribution (CC BY) license (http://creativecommons.org/licenses/by/4.0/). 